\title{
Application of manual therapy in muscle tensional dysphonia
}

\section{Primena manuelne terapije kod mišićnih tenzionih disfonija}

\author{
Stevan S. Jovanovic ${ }^{1}$, Sladjana D. Arsic ${ }^{2}$, \\ Biljana N. Stojanovic Jovanovic ${ }^{1}$, Dragana M. Kljajic ${ }^{1}$, \\ Marija T. Trajkov ${ }^{1}$ \\ 1. Academy of Applied Studies Belgrade, TheCollege of Health Sciences, Belgrade, \\ Serbia \\ 2. The Academy of Applied Preschool Teaching and Health Studies, Krusevac, \\ Department Cuprija, Cuprija \\ RECEIVED 23.06.2020 \\ ACCEPTED $\quad 22.10 .2020$.
}

\author{
Stevan S. Jovanović1 Slađana D. Arsić ${ }^{2}$, \\ Biljana N. Stojanović Jovanović ${ }^{1}$, Dragana M. Kljajić ${ }^{1}$, \\ Marija T. Trajkov ${ }^{1}$ \\ 1. Akademija strukovnih studija Beograd, Odsek Visoka zdravstvena škola \\ Beograd \\ 2. Akademija vaspitačko-medicinskih strukovnih studija Kruševac, Odsek Ćuprija, \\ Ćuprija \\ PRIMLJEN 23.06.2020 \\ PRIHVAĆEN 22.10.2020.
}

\begin{abstract}
Muscle tension dysphonia is a functional voice disorder caused by unbalanced activity of the laryngeal and extralaryngeal muscles. People with dysphonia may have changes in the cervical and perilaryngeal muscles, limited amplitude of movement of the cervical spine, but also posture disorders. The aim of this paper is to present the analyzed therapeutic effects of manual techniques in muscle tension dysphonia, based on a review of the available literature. In accordance with the set criteria and the goal of the paper, the collection and analysis of professional and scientific research papers available in PubMed / MEDLINE databases and others, published in the period from 2004 to 2018, was performed. The analyzed studies belong to the type of clinical studies and by design, two types of studies are included: the type of randomized control study and the study of one group of subjects with before- and after-examination. Some studies with one group of respondents were characterized by the authors as a series of cases and one, as a small pilot study of repeated measures. The results of the research indicate a larger number of corrective effects of laryngeal manual therapy. It is certain that by developing a broader manual-therapeutic approach, the etiological factor of muscle tension dysphonia can be more effectively influenced which leads to a reduction in pain, improvement of physical functioning as well as improvement of specific vocal qualities.
\end{abstract}

Key words: voice; voice disorders; dysphonia; therapeutics; musculoskeletal manipulations.

\section{APSTRAKT}

Mišićna disfonija je funkcionalni poremećaj glasa nastao zbog neizbalansirane aktivnosti laringealnih i ekstralaringealnih mišića. Osobe sa disfonijom mogu imati promene na cervikalnoj i perilaringealnoj muskulaturi, ograničenje amplitude pokreta cervikalne kičme, ali i poremećaje posture. Cilj rada je da prikaže analizirane terapijske efekte manuelnih tehnika kod mišićnih tenzionih disfonija na osnovu pregleda dostupne literature. U skladu sa postavljenim kriterijumima i ciljem rada, izvršeno je prikupljanje i analiza stručno-naučnih istraživačkih radova dostupnih u bazama PubMed/MEDLINE i drugim, objavljenih u periodu od 2004. do 2018. godine. Analizirane studije pripadaju tipu kliničkih studija a po dizajnu, uključene su studije dva tipa: tip randomizovane kontrolisan studije i studije jedne grupe ispitanika sa pre- i postispitivanjem. Pojedine studije sa jednom grupom ispitanika su od samih autora okarakterisane kao serije slučajeva, a jedna kao mala pilot studija ponovljenih mera. Rezultati istraživanja ukazuju na veći broj korektivnih efekata laringealne manuelne terapije. Izvesno je da se razvijanjem šireg manuelno-terapeutskog pristupa može efektnije uticati i na etiološki faktor mišićne tenzione disfonije što vodi ka smanjenju bola, unapređenju fizičkog funkcionisanja kao i unapređenju specifičnih vokalnih kvaliteta.

Ključne reči: glas; poremećaji glasa; disfonija; terapija; muskuloskeletne manipulacije. 


\section{INTRODUCTION}

It is noticeable, that in current scientific literature, the authors use the term muscle-tension dysphonia (MTD) to indicate a functional voice disorder that is associated with incorrect or uneven muscular activity during phonation. ${ }^{1}$ MTD is sometimes defined by the literature as hyperfunctional voice disorders. Excessive pressure and tension of the extralaryngeal muscles is considered to be the main clinical indicator of MTD. ${ }^{2}$

People with dysphonia may have changes in the cervical and perilaryngeal musculature, muscle pain during rest or during certain functional activity, hyperactivity of the external laryngeal muscles, limitation of the amplitude of cervical spine movement, and also posture disorders. ${ }^{3-5}$ It is assumed these disorders disrupt the normal automation of phonatory production. If this process takes longer, it disrupts the activity of the voice-producing organs and makes phonation increasingly difficult. Most patients experienced a "locked voice" or the inability to adjust the vibration frequency to adjust the pitch as the inability to modulate the volume. This disrupts the "flexibility and dynamic volume of the voice" when speaking and singing. The voice produced by MTD can be harsh, hoarse, like a whisper, tense, etc.

Apart from disorders of phonation, articulation and vocal function, there are broader changes in the functioning of the musculoskeletal system, such as reduced buccal opening, anterior displacement of the head and neck, elevated or rounded shoulder girdle, torso flexion, increased thoracic kyphosis and decreased cervical and thoracic rotation.

A large number of studies show that manual therapies have played a significant role in the treatment and rehabilitation of muscle tension dysphonia. The most commonly used manual-therapeutic approaches are mobilization and manipulation of joints, myofascial release, nerve manipulation, acupressure and others. Aronson first described manual treatment to reduce musculoskeletal tension associated with vocal hyperfunction in the 1990s.6 Subsequently, a number of practitioners from a variety of disciplines, including speech pathology, osteopathy, and physical therapy, have developed manual therapy techniques designed to be used in the treatment of voice disorders. ${ }^{7-10}$ As a result, manual techniques intensively come into use in the treatment of muscle tension dysphonia, and the rapidly growing volume of literature appearing in this field has begun to provide a base of evidence for the effectiveness and efficiency of these approaches.

One of the newer manual-therapeutic methods used in the voice rehabilitation of patients with muscle tension dysphonia is application of manual circumlaryngeal therapeutic technique (CMT). This manual technique involves the application of active and passive force in the form of circular massage movements, kindling as well as stretching on the extralaryngeal and articular muscles, and includes shifting the position of the larynx while acting on the trigger point. ${ }^{11}$ The primary goal of manual techniques applied on the perilaryngeal and laryngeal area is to relax muscles of excessively elevated tension that inhibit normal phonator function.

According to Aronson, in vocal hyperfunction caused by increased musculoskeletal tension, the larynx and hyoid bone are elevated in relation to the position they occupy during normal function. ${ }^{6}$ Such a phenomenon is present in people with muscular tension dysphonia, and some authors state that it can be assumed that the external laryngeal muscles that raise the larynx also affect the way the vocal cords vibrate. ${ }^{12-14}$ It is also believed, that the vertical position of the larynx can affect the phonator function, by changing the length and tension of the vocal cords and thus contributing to the disturbance of voice quality. ${ }^{15,16}$ Based on this, it can be concluded that strategies aimed at relaxing the increased tension of the perilaryngeal musculature may improve glottal function. ${ }^{17}$

\section{MATERIAL AND METHODS}

In accordance with the subject of this paper, the appropriate professional and scientific articles, were collected and analyzed. Using a selection method based on the proposed criteria, an articles were selected by searching the electronic database (PubMed, The United States National Library of Medicine (NLM) at the National Institutes of HealthPubmed); ScienceDirect (Elsevier); SciELO (The Scientific Electronic Library Online), Open Access, Consortium of Libraries of Serbia for Unified Procurement (KoBSon).

For amore precise review of the literature, search criteria have been set. All published and analyzed publications are in English language. Published studies belong to the type of clinical studies. By design, the included studies were a randomized control study (existence of more than one group of subjects) and studies of one group of subjects with before-after examination. Some studies with one group of respondents were characterized by the authors themselves as a series of cases and one as a small pilot study of repeated measures. The scope of the analyzed articles was limited to eight papers, published at full length, over the period from 2004 to 2018. The keywords used in the search were: muscular tension dysphonia, laryngeal manual therapy, voice, vocalization, pain, function. 


\section{RESULTS}

The main results are presented within the five tables. Overview of analyzed studies by author, source, source category, year of publication and type of study was presented in table 1 . Table 2 presents the age and gender of participants and condition of the studies. Other tables included the review of analyzed studies by variables (criteria) for evaluation of treatment results (table 3), theeview of analyzed studies according to the description of treatment (table 4) and thereview of analyzed studies by treatment outcome (table 5).

Table 1. Overview of analyzed studies by: author, source, source category, year of publication and type of study.

\begin{tabular}{|c|c|c|c|c|c|}
\hline No. & Authors & Source & $\begin{array}{l}\text { Source } \\
\text { category }\end{array}$ & Year & Type of study \\
\hline 1. & Reimannet al. & $\begin{array}{l}\text { CoDAS (Commu- } \\
\text { nication Disorders, } \\
\text { Audiology and } \\
\text { Swallowing) }\end{array}$ & Journal & 2016. & $\begin{array}{c}\text { Clinical } \\
\text { prospective } \\
\text { nonrandomized } \\
\text { study }\end{array}$ \\
\hline 2. & $\begin{array}{l}\text { Mathieson } \\
\text { et al. }\end{array}$ & Journal of Voice & Journal & 2009. & $\begin{array}{l}\text { A small pro- } \\
\text { spective study }\end{array}$ \\
\hline 3. & $\begin{array}{l}\text { Van Lierde } \\
\text { et al. }\end{array}$ & Journal of Voice & Journal & 2004. & Case study \\
\hline 4. & Roy et al. & $\begin{array}{l}\text { Journal of Commu- } \\
\text { nication Disorders }\end{array}$ & Journal & 2009. & $\begin{array}{l}\text { Nonrandom- } \\
\text { ized clinical } \\
\text { trial }\end{array}$ \\
\hline 5. & $\begin{array}{l}\text { Tomlinson } \\
\text { and Archer }\end{array}$ & Physical Therapy & Journal & 2014. & Case study \\
\hline 6. & $\begin{array}{l}\text { Alves Silverio } \\
\text { et al. }\end{array}$ & Journal of Voice & Journal & 2015. & $\begin{array}{c}\text { Randomized } \\
\text { controlled trial } \\
\text { (RCT) }\end{array}$ \\
\hline 7. & Conde et al. & Journal of Voice & Journl & 2018. & $\begin{array}{c}\text { Randomized } \\
\text { controlled trial } \\
\text { - RCT }\end{array}$ \\
\hline 8. & $\begin{array}{c}\text { Rezaee Radet } \\
\text { al. }\end{array}$ & $\begin{array}{c}\text { Shiraz E-Medical } \\
\text { Journal }\end{array}$ & Journal & 2018. & $\begin{array}{l}\text { Quasi-experi- } \\
\text { mental study }\end{array}$ \\
\hline
\end{tabular}

Table 2. Review of analyzed studies by: authors, number, age and gender of participants and condition.

\begin{tabular}{|c|c|c|c|c|c|c|c|c|}
\hline \multirow[b]{2}{*}{ No. } & \multirow{2}{*}{ Authors } & \multirow{2}{*}{$\begin{array}{l}\text { Study } \\
\text { sample } \\
\text { (n) }\end{array}$} & \multirow{2}{*}{$\begin{array}{l}\text { Experi- } \\
\text { mental } \\
\text { group }(\mathrm{n})\end{array}$} & \multirow{2}{*}{$\begin{array}{l}\text { Control } \\
\text { group } \\
(n)\end{array}$} & \multirow{2}{*}{ Age(range/mean) } & \multicolumn{2}{|c|}{ Gender } & \multirow{2}{*}{$\begin{array}{l}\text { Diagnosis- } \\
\text { condition }\end{array}$} \\
\hline & & & & & & $M$ & $\mathrm{~F}$ & \\
\hline 1. & $\begin{array}{l}\text { Reimannet } \\
\text { al., } 2016\end{array}$ & 30 & 15 & 15 & F: $27.6 \mathrm{M}: 26.6$ & 3 & 12 & $\begin{array}{c}\text { Functional } \\
\text { dysphonia } \\
\text { (MTD) }\end{array}$ \\
\hline 2. & $\begin{array}{c}\text { Mathieson et } \\
\text { al., } 2009\end{array}$ & 10 & - & - & $19-55$ (30.3) & 2 & 8 & MTD \\
\hline 3. & $\begin{array}{l}\text { Van Lierdeet } \\
\text { al., } 2004\end{array}$ & 4 & - & - & $37-60$ & 2 & 2 & $\begin{array}{l}\text { Vocal hy- } \\
\text { perfunction } \\
\text { (MTD) }\end{array}$ \\
\hline 4. & $\begin{array}{c}\text { Roy et al., } \\
2009\end{array}$ & 111 & - & - & 46.12 & & 111 & MTD \\
\hline 5. & $\begin{array}{l}\text { Tomlinson } \\
\text { and Archer, }\end{array}$ & 9 & - & - & - & - & - & MTD \\
\hline 6. & $\begin{array}{l}\text { AlvesSilverio } \\
\text { et al., } 2015\end{array}$ & 20 & 10 & 10 & $18-45$ & - & 20 & MTD \\
\hline 7. & $\begin{array}{c}\text { Condeet al., } \\
2018\end{array}$ & 30 & 15 & 15 & $\begin{array}{l}18-45(28.70 \pm \\
6.75)\end{array}$ & & 30 & $\begin{array}{c}\text { Behavioral } \\
\text { dysphonia- } \\
\text { MTD }\end{array}$ \\
\hline 8. & $\begin{array}{l}\text { Rezaee Rad } \\
\text { et al., } 2018\end{array}$ & 20 & - & - & $\begin{array}{l}F: 23-42(34.1) \\
M: 34-41(37.6)\end{array}$ & 8 & 12 & MTD \\
\hline
\end{tabular}


REVIEW ARTICLE / PREGLEDNI RAD

PONS Medical Journal / PONS Medicinski časopis

Table 3. Review of analyzed studies by variables (criteria) for evaluation of treatment results

\begin{tabular}{|c|c|c|c|c|c|}
\hline \multirow{3}{*}{ No. } & \multirow{3}{*}{ Study } & \multicolumn{4}{|c|}{ Assessments } \\
\hline & & \multicolumn{2}{|c|}{ Assessment of vocal qualities } & \multicolumn{2}{|c|}{ Assessment of physicalcharacteristics } \\
\hline & & $\begin{array}{l}\text { Subjective (self-assess- } \\
\text { ment) }\end{array}$ & Objective & Subjective (self-assessment) & Objective \\
\hline 1. & $\begin{array}{l}\text { Reimannet al., } \\
2016\end{array}$ & $\begin{array}{l}\text { Immediate feelings re- } \\
\text { garding voice, larynx and } \\
\text { articulation }\end{array}$ & $\begin{array}{l}\text { Apparatus acoustic analysis; } \\
\text { Non-instrumental analysis of vocal char- } \\
\text { acteristics by experts. }\end{array}$ & $\begin{array}{l}\text { Musculoskeletal Pain Questionnaire: in- } \\
\text { tensity of pain of temporal regions, lar- } \\
\text { ynx, posterior and anterior side of neck, } \\
\text { spine and extremity joints }\end{array}$ & - \\
\hline 2. & $\begin{array}{l}\text { Mathieson et } \\
\text { al., } 2009\end{array}$ & - & $\begin{array}{l}\text { Apparatus acoustic analysis (laryngo- } \\
\text { graph) }\end{array}$ & The vocal tract discomfort scale-VTD & $\begin{array}{l}\text { Palpation evaluation of } \\
\text { perilaryngeal musculature }\end{array}$ \\
\hline 3. & $\begin{array}{l}\text { Van Lierde et } \\
\text { al., } 2004\end{array}$ & & $\begin{array}{l}\text { Auditory-perceptual evaluation: assess- } \\
\text { ment by the "human ear" by two experts, } \\
\text { using the scale for the assessment of dys- } \\
\text { phonia (GRBAS scale); } \\
\text { Apparatus analysis using a scale to assess } \\
\text { the severity of dysphonia (Dysphonia Se- } \\
\text { verity Index-DSI). }\end{array}$ & - & Videolaryngostroboscopy \\
\hline 4. & Roy et al., 2009 & - & $\begin{array}{l}\text { Apparatus acoustic analysis; } \\
\text { Human auditory assessment by five peo- } \\
\text { ple. }\end{array}$ & - & - \\
\hline 5. & $\begin{array}{l}\text { Tomlinson and } \\
\text { Archer, } 2015\end{array}$ & $\begin{array}{l}\text { Self - assessment of the } \\
\text { impact of vocal disability } \\
\text { (Voice Handicap Index - } \\
\text { VHI) }\end{array}$ & - & $\begin{array}{l}\text { Semi-structured interview; } \\
\text { Pain (Numerical scale of pain); } \\
\text { Self-assessment of functional status } \\
\text { (Patient Specific Functional Scale - } \\
\text { PSFS). }\end{array}$ & $\begin{array}{l}\text { Physical therapeutic } \\
\text { examination; } \\
\text { Functional status. }\end{array}$ \\
\hline 6. & $\begin{array}{l}\text { Alves Silverio } \\
\text { et al., } 2015\end{array}$ & & $\begin{array}{l}\text { Apparatus auditory-perceptual analysis of } \\
\text { voice; } \\
\text { Perceptual analysis of the image by the } \\
\text { "human ear" by three experts. }\end{array}$ & $\begin{array}{l}\text { Musculoskeletal pain (Nordic muscu- } \\
\text { loskeletal symptoms questionnaire - } \\
\text { NMSQ); } \\
\text { Visual analog pain scale. }\end{array}$ & \\
\hline 7. & $\begin{array}{l}\text { Condeet al., } \\
2018\end{array}$ & & $\begin{array}{l}\text { Apparatus acoustic analysis of voice; Per- } \\
\text { ceptual analysis of the image by the "hu- } \\
\text { man ear" by three experts. }\end{array}$ & $\begin{array}{l}\text { The Musculoskeletal Pain Investigation } \\
\text { questionnaire; } \\
\text { Visual analog pain scale. }\end{array}$ & \\
\hline 8. & $\begin{array}{l}\text { Rezaee Radet } \\
\text { al., } 2018\end{array}$ & & $\begin{array}{l}\text { Apparatus acoustic analysis of voice } \\
\text { (PRAAT version 5.4.12) }\end{array}$ & The vocal tract discomfort scale-VTD & \\
\hline
\end{tabular}


Table 4. Review of analyzed studies according to the description of treatment

\begin{tabular}{|c|c|c|c|c|c|}
\hline No. & Study & Treatment & Description of treatment & $\begin{array}{c}\text { Duration } \\
(\mathrm{min})^{*}\end{array}$ & $\begin{array}{l}\text { Number of } \\
\text { treatments }\end{array}$ \\
\hline 1. & $\begin{array}{l}\text { Reimannet al., } \\
2016\end{array}$ & LMT CMT & $\begin{array}{l}\text { - Five minutes of massage - sternocleidomastoid; } \\
\text { - Five minutes of massage - suprahyoid area; } \\
\text { - Repeat } 3 \text { minutes of sternocleidomastoid massage; } \\
\text { - Repeat } 3 \text { minutes of massage-suprahyoid area; } \\
\text { - } 2 \text { minutes of sliding and lowering of the larynx; } \\
\text { - two minutes of relocation in the thyroid area. }\end{array}$ & 20 & 1 \\
\hline 2. & $\begin{array}{l}\text { Mathieson et } \\
\text { al., } 2009\end{array}$ & LMT and CMT & $\begin{array}{l}\text { LMT: } \\
\text { (1) Circular massage SCMs (bimanual) } \\
\text { (2) Kneading of the supralaringeal area (unimanual) } \\
\text { (3) Hyoid bone massage (unimanual massage from one side to the other) } \\
\text { (4) Bimanual depression of the larynx with the fingers at the upper border of the thyroid } \\
\text { cartilage. } \\
\text { (5) the larynx is moved laterally by alternate application of bimanual digital pressure } \\
\text { CMT: } \\
\text { (1) Circular pressure on hyoid (unimanual) } \\
\text { (2) A procedure that is repeated within the thyroid space. } \\
\text { (3) Recurrent beyond the posterior borders of the thyroid cartilage } \\
\text { (4) The larynx is retracted, with the fingers above the upper border of the thyroid cartilage, } \\
\text { and occasionally moves }\end{array}$ & 45 & \\
\hline 3. & $\begin{array}{l}\text { Van Lierde et } \\
\text { al., 2004 }\end{array}$ & LMT & $\begin{array}{l}\text { 1. Correction of general posture and especiallyhead position ( } 5 \text { minutes) } \\
\text { Abdominal exercisebreathing at rest while sitting, when standing, and while walking ( } 5 \text { min- } \\
\text { utes) } \\
\text { 3. Exercise abdominal breathingduring phonation ( } 5 \text { minutes) } \\
\text { 4. Positioning in a relaxed position ( } 2 \text { minutes) } \\
\text { 5. Manipulation of different muscles ( } 20 \text { minutes) } \\
\text { 6. After manipulating different muscles, approach to vocalization by Bonn and McFarlane } \\
\text { (10 minutes) } \\
7 \text {. The open mouth approach is repeated withusual vocalization ( } 5 \text { minutes) } \\
\text { 8. Procedures } 1-7 \text { were repeated during } 25 \text { therapy sessions, at least once, but mostly twice } \\
\text { a week } \\
\text { 9. Subjects were ordered to repeatstretching the thyroid muscle, singingand open-mouth ac- } \\
\text { cess at home during5 minutes, twice a day }\end{array}$ & 62 & 25 \\
\hline 4. & Roy et al., 2009 & LMT, CMT & Circumlaringeal massage and Laryngeal reposition & - & 1 \\
\hline 5. & $\begin{array}{l}\text { Tomlinson CA, } \\
\text { Archer KR. }\end{array}$ & $\begin{array}{l}\text { LMT, CMT Exercises } \\
\text { Relaxation }\end{array}$ & $\begin{array}{l}\text { Program of home exercises-techniques of progressive relaxation for the whole body; cervi- } \\
\text { cal stretching, and self - administration of therapy (training in circumlaringeal massage by } \\
\text { Matison; ergonomic and instructions on proper posture); manual therapy of the laryngeal } \\
\text { region and the posterior cervical and scapular regions; therapeutic massage; release of trig- } \\
\text { ger points; hip flexor exercises. }\end{array}$ & 60 & 18 \\
\hline 6. & $\begin{array}{l}\text { Alves Silverio } \\
\text { et al., } 2015\end{array}$ & $\begin{array}{l}\text { LMT, CMT and } \\
\text { Transcutaneous } \\
\text { Electrical Nerve } \\
\text { Stimulation-TENS }\end{array}$ & $\begin{array}{l}\text { Massage of the sternocleidomastoid, suprahyoid and laryngeal musculature with circulatory } \\
\text { movements with "kneading" and stretching of each muscle group (according to Matison); } \\
\text { Application of TENS to the upper trapezius region bilaterally and in the submandibular region, } \\
\text { bilaterally. }\end{array}$ & $\begin{array}{l}20 \mathrm{MT}+ \\
\text { 20TENS }\end{array}$ & 12 \\
\hline 7. & $\begin{array}{l}\text { Condeet al., } \\
2018\end{array}$ & $\begin{array}{l}\text { LMT, CMT and } \\
\text { Transcutaneous } \\
\text { Electrical Nerve } \\
\text { Stimulation-TENS }\end{array}$ & $\begin{array}{l}\text { Massage of the sternocleidomastoid, suprahyoid and laryngeal musculature with circulatory } \\
\text { movements with "kneading" and stretching of each muscle group (according to Matison); } \\
\text { Application of TENS to the upper trapezius region bilaterally and in the submandibular region, } \\
\text { bilaterally. }\end{array}$ & $\begin{array}{l}20 \mathrm{MT}+ \\
\text { 20TENS }\end{array}$ & 1 \\
\hline 8. & $\begin{array}{l}\text { Rezaee Radet } \\
\text { al., } 2018\end{array}$ & LMT, CMT & $\begin{array}{l}\text { Repositioning maneuvers with the aim of eliminating irregular patterns of muscle activity; } \\
\text { Compression of the larynx using antero-posterior pressure ("hyoid pushback"); } \\
\text { The maneuver presses down on the upper corner of the laryngeal cartilage ("pull-down"); } \\
\text { Rotary massage by "kneading" the extralaryngeal region (according to Roy, Leeper and Ar- } \\
\text { onson) }\end{array}$ & - & 1 \\
\hline
\end{tabular}

The population of the reviewed studies includes subjects with diagnosed muscular tension dysphonia. Given the methodological inhomogeneity of the selected studies, there is a difference in the number of respondents that varies from only four in the study of Van der Lierde and associates (2), to one hundred and eleven by Roy and associates.,18 Among the respondents, a noticeably higher number of females is observed. The age range of the respondents in the studies is from 19 to 60 .

There were different criteria and measures of treatment outcomes in the studies. They included the assessment of vocal characteristics, which we systematized through two categories, as objective and as subjective or self-assessment.
The second aspect of the assessment referred to body categories, which are also divided into two categories: objective (expert review) and subjective or self-assessment. The following body categories were assessed: pain, mobility and range of motion (larynx and joints). Degree of muscle tension.

Four of the eight studies reviewed the determination of the immediate effects of manual therapies for the treatment of dysphonia that occurred after only one treatment. In a study by Reimann and associates after the application of one treatment of laryngeal manual therapy in dysphonia, immediate effects were observed in the form of reduced 
Table 5. Review of analyzed studies by treatment outcome

\begin{tabular}{|c|c|c|c|c|}
\hline & & Voice quality & The pain & Other parameters \\
\hline 1. & $\begin{array}{l}\text { Reimannet al., } \\
2016\end{array}$ & $\begin{array}{l}\text { "Perceptual-auditory analysis of the vowel "a" -there was no dif- } \\
\text { ference after the application of LMT in all estimated parameters } \\
\text { of both groups } \\
\text { *55.6\% of individuals in dysphonic group presented "better" } \\
\text { "Global impression of voice quality after LMT } \\
\text { "Spontaneous speech, -perceptive-auditory analysis-impaired } \\
\text { roughness after LMT in the dysphonic group, for other param- } \\
\text { eters, there was no difference after LMT in both analyzed groups } \\
\text { "There were no differences in the group of dysphonists in more } \\
\text { than } 70 \% \text { of the sample after LMT. }\end{array}$ & $\begin{array}{l}\text { Immediate effects: } \\
\text { Reduction of pain in the temporal, la- } \\
\text { ryngeal region, posterior regions of the } \\
\text { neck, spine, hips, thighs, arms and hands. }\end{array}$ & - \\
\hline 2. & $\begin{array}{l}\text { Mathieson et al., } \\
2009\end{array}$ & $\begin{array}{l}\text { Significantly reduced relative average perturbation during as- } \\
\text { sociated speech, after LMT, indicating a decrease in abnormal } \\
\text { vocal function. }\end{array}$ & - & $\begin{array}{l}\text { Weight and frequency on } \\
\text { the VTD scale, decreased } \\
\text { after LMT. }\end{array}$ \\
\hline 3. & $\begin{array}{l}\text { Van Lierde et al., } \\
2004\end{array}$ & $\begin{array}{l}\text { *In all subjects' improvement on GRBAS and DSI scales; } \\
\text { "In three of the four respondents, improved; } \\
\text { *Perceptual impression of roughness and vocal intensity. }\end{array}$ & - & - \\
\hline 4. & Roy et al., 2009 & $\begin{array}{l}\text { *Perceptual characteristics of MTD significantly reduced (assess- } \\
\text { ment of } 5 \text { listeners); } \\
\text { "Improved acoustic metrics that reflect improved vocal tract } \\
\text { dynamics and articulatory movements during vowel production. }\end{array}$ & - & - \\
\hline 5. & $\begin{array}{l}\text { Tomlinson and } \\
\text { Archer, } 2015\end{array}$ & & $\begin{array}{l}\text { Eight patients stopped pain after treat- } \\
\text { ment. }\end{array}$ & $\begin{array}{l}\text { All } 9 \text { patientsshowed im- } \\
\text { provement in PSFS score; } \\
\text { In } 7 \text { patients } \\
\text { clinically significant improve- } \\
\text { ment at the end of the } \\
\text { intervention. } \\
\text { Three patients had a } \\
\text { clinically significant change in } \\
\text { VHI scores } \\
\text { All } 9 \text { patients showed } \\
\text { improvement in cervical } \\
\text { flexion and lateralflexion and } \\
\text { opening of the jaw; } \\
\text { Eight patients improved in } \\
\text { cervical extension and rota- } \\
\text { tion after the intervention. }\end{array}$ \\
\hline 6. & $\begin{array}{l}\text { Alves Silverio et } \\
\text { al., } 2015\end{array}$ & $\begin{array}{l}\text { Application of TENS: there has been a significant improvement } \\
\text { in the production of "treble"the "tension" parameter in the voice } \\
\text { is significantly improved, after application; } \\
\text { LMT application: voltage parameter is not improved }\end{array}$ & $\begin{array}{l}\text { Application of TENS: Significantly lower } \\
\text { frequency of pain in the back of the neck } \\
\text { and shoulders and back; } \\
\text { Application of LMT: reduced symptoms } \\
\text { of "sore throat", significantly lower fre- } \\
\text { quency and reduction of pain intensity } \\
\text { in the anterior and posterior cervical re- } \\
\text { gion. }\end{array}$ & $\begin{array}{l}\text { Application of TENS: reduced } \\
\text { speech effort; } \\
\text { LMT application: - }\end{array}$ \\
\hline 7. & Condeet al., 2018 & $\begin{array}{l}\text { Application of TENS: there has been an improvement in vowel } \\
\text { production (reduction of instability); Improving laryngeal func- } \\
\text { tion and articulation. } \\
\text { Application of LMT: general improvement of voice quality, } \\
\text { reduction of tension and reduction of breathing sound in speech; } \\
\text { Improving laryngeal function and articulation. }\end{array}$ & $\begin{array}{l}\text { Application of TENS: reduction of pain } \\
\text { intensity in the back or front part of the } \\
\text { neck, shoulders, upper or lower back and } \\
\text { in the maseter muscles; } \\
\text { Application of LMT: reduction of pain } \\
\text { intensity in the front part of the neck, } \\
\text { shoulders, lower back and temporal re- } \\
\text { gion. }\end{array}$ & \\
\hline 8. & $\begin{array}{l}\text { Rezaee Rad et al., } \\
2018\end{array}$ & $\begin{array}{l}\text { Vocal jitter and flicker are significantly reduced as well as im- } \\
\text { proved harmonic composition and noise reduction after LMT. }\end{array}$ & & \\
\hline
\end{tabular}

pain intensity in the temporal regions, posterior neck and lower and upper parts of the spine (Table 5). ${ }^{19}$ The authors conclude that muscle pain in dysphonists is present as a result of their increased tension, i.e. muscle tone. Also, it is possible to restore the tonal balance in the muscles distally and proximal to the larynx, by acting with laryngeal manual therapy because its effect is to improve blood circulation in the regions of application.

A significantly higher number of females participated in all analyzed studies. According to astudy by Cohen and associates, which wasconducted as a retrospective analysis of data from a large US national database, it was found that of the nearly 55 million people within the database, 536,943 patients (years of age from 0 to $>65$ ) had a diagnosis of dysphonia (prevalence rate $0.98 \%$ ) $^{20}$. The prevalence rate was higher in females ( $1.2 \%$ vs. $0.7 \%$ ) and in persons older than 70 years. ${ }^{20}$ One of the studies included in this analysis, states that females are much more often patients in clinics for the treatment of voice disorders and that they are much more likely to develop dysphonia than men. ${ }^{21}$ The authors state that the glottis in women is much smaller and that it is the cause of more frequent dysphonia. ${ }^{22}$ 


\section{DISCUSSION}

Muscle tension dysphonia as a functional disorder of the voice, is most often a consequence of unbalanced activity of the laryngeal and extralaryngeal muscles. Aronson first described manual treatment to reduce musculoskeletal tension and then, a large number of practitioners from different disciplines, designed manual techniques used in the treatment of voice disorders. ${ }^{6-10}$ As a result, manual techniques are intensively used in the treatment of muscular tension dysphonia. In addition, the growing body of literature in this area is providing a base of evidence for the effectiveness and efficiency of these approaches.

In the current literature, the most frequently mentioned manual technique in the treatment of muscular dysphonia is laryngeal manual therapy (LMT). In addition to having an analgesic effect, it can achieve muscle rebalance in the perilaryngeal region. Some studies show that after the application of LMT, the voice tension is reduced, and that the symptoms of hoarseness and roughness of the voice are reduced as well. ${ }^{19}$

On the other hand, in a study that was reviewed and also considered within our comparison, which was aimed to evaluate the effects of one type of LMT applied in 25 sessions, an improvement in voice qualitywas found 23 . However, it should be kept in mind, that this is not a direct effect of one treatment session, but a longer period of time with the application of a larger number of treatments and with the training of respondents.

In the research of Rezaee Rad and co-workers, the immediate, positive effect of circumlaryngeal manual therapy - CMT on the reduction of symptoms of the voice tremor during vocal production is emphasized. ${ }^{24}$ The study by Conde and colleaguesaimed to determine the immediate effects of a single treatment of TENS and LMT on musculoskeletal pain (subjective pain sensation) and vocal quality in females (ages 18-45), with functional and organo-functional dysphonia (increased muscle tension). ${ }^{21}$ In the study, TENS was applied, which led to strong but pleasant muscle contractions in the region where it was applied. This resulted in muscle relaxation and pain reduction. ${ }^{21,25}$ The authors of the study, found reduced pain in the subjects, not only in the regions where TENS was applied directly, but also in those that are distant (shoulders and lower back region). A possible explanation, is that the electrodes are placed on the fibers of the descending part of the trapezius muscle (m. trapezius pars descendens), which are myofascial trigger points, and therefore pain is minimized in certain areas. Another explanation given by the authors of this study is that the reduction of pain under the influence of TENS occurs due to the release of opioid peptides in the cerebrospinal fluid, basing this assumption on the conclusions of previous studies by other authors. ${ }^{26,27}$
In addition to the analgesic effect of TENS, a study by Conde and associates noted a direct reduction in the intensity of pain in the temporal regions, neck and shoulders after LMT treatment. Regarding the perceptual analysis of the voice, the autors conclude that TENS works by leading to a significant improvement in vowel instability / a /. They believe that this improvement is due to the strengthening of the vocal mucosa and the improvement of the balance between the internal and external laryngeal muscles, which contributes to the appropriate closure of the vocal folds and balances the aerodynamic and myoelastic forces 21 . The subjective feeling of the respondents with dysphonia, after the application of TENS, was described as "stronger", "cleaner", "less rough", "more relaxed" voice. The most common laryngeal signs were "less effort and strain" in speech (80\%). The group that had LMT felt a significant subjective improvement in the larynx and in articulation. The most commonly described subjective signs were a feeling of lightness and relaxation ${ }^{21}$.

An analysis of a study similar in design to the previous one, which included 20 female subjects aged 18-45 years (as in the previous study) with dysphonia, showed that low-frequency TENS application for 12 sessions managed to reduce some vocal and laryngeal symptoms such as high-pitched voice and subjective feeling of speech effort. ${ }^{28}$ In addition, the effect of TENS on reducing the frequency and intensity of pain in the posterior neck and shoulders was observed. The effect of LMT led to a reduction in symptoms such as "sore throat", but also to the frequency of musculoskeletal pain in the front part of the neck and a decrease in the intensity of pain in the posterior region of the neck. The authors of this study believe that LMT and TENS are complementary methods of treating people with dysphonia and that they are good therapeutic resources but that additional speech therapy is needed in terms of laryngeal and vocal aspects.

A study by Mathieson and associates that was conducted to investigate the effects of manual therapy treatment in resolving muscular tension dysphonia, established the positive effects of LMT as a method in the treatment of hyperfunctional voice disorders. It has been shown that these effects are measurable both by applying acoustic analysis and by applying the Vocal Tract Discomfort Scale. The vocal tract discomfort scale is a useful tool as a perceptual indicator of sensory changes before and after LMT application. ${ }^{17}$

Furthermore, the authors present the fact that after the application of LMT, patients have positive kinesthetic changes in terms of phonation itself, but also the quality of the voice. Mathieson believes that the required time or length of LMT application period varies according to the patient's response to the procedure and that it is not always the case that higher levels of muscle tension in patients require a longer treatment period. 
The results of a study by Carrie Tomlinson and Christine Archer, designed as a case series design to assess the feasibility and effectiveness of Vanderbilt Manual Intervention (VMI) in patients with MTD, indicate that there is an improvement of the functional status on the Patient-Specific Functional Scale (PSFS) ${ }^{29}$. The authors believe that this is because Vanderbilt is a manual intervention - a VMI program, that by its nature, focuses on reducing muscle tension in the neck, jaw, shoulder girdle, chest and psoas major muscles. In addition, the opinion of the author is that a broader manual-therapeutic approach may have an impact on the etiological factor $\mathrm{MTD}^{29}$.

From the results of most of the analyzed and presented studies, it can be concluded that the implementation of manual-therapeutic skills in patients with muscular tension dysphonia leads to the achievement of positive effects and improvement of functional outcomes. Although the period from 2004 to 2018 was fully covered for the review and analysis of published articles, yet, the scope of the analyzed papers is limited to eight papers. That was certainly not enough for a more precise conclusion, but it served as a basic basis for further research on the topic.

\section{CONCLUSIONS}

Muscle tension dysphonia is a health problem reflecting several aspects. In addition to problems and disorders of vocal production, there is also a problem of local or possibly general musculoskeletal functioning, and especially the occurrence of musculoskeletal pain. Manual therapies of LMT and CMT, respectively, are the methods of choice in resolving vocal and musculoskeletal dysfunctions that occur within MTD. The analysis of the papers indicates growing evidence that LMT not only has a local effect on the muscles of the laryngeal and perilaryngeal regions, but also has a beneficial effect on reducing the symptoms of pain and muscle tension in more distant regions of the body. A number of corrective effects of LMT have also been observed.

It is certain, that by developing a broader manual-therapeutic approach, the etiological factor MTD can be more effectively influenced, which leads to pain reduction, improvement and improvement of physical functioning and, of course, improvement of specific vocal qualities. Given that laryngeal manual therapy is by its nature a borderline area of work, which in practice is part of the professional activities of a number of different professionals, it can be concluded that a multidisciplinary approach is essential to innovate and improve practice in this area.

\section{REFERENCES}

1. Hočevar Boltežar I. Muscle tension dysphonia. ZdravVestn 2019;73: 605-9. (in Slovenian).

2. Van Houtte E, Van Lierde K, Claeys S. Pathophysiology and treatment of muscle tension dysphonia: a review of the current knowledge. J Voice 2011; 25: 202-7.

3. Bigaton DR, Silvério KCA, Berni KCS, Distefano G, Forti F, Guirro RRJ. Craniocervical posture in dysphonic women. Rev Soc Bras Fonoaudiol 2010; 15: 329-34. (in Portuguese).

4. Angsuwarangsee T, Morrison M. Extrinsic laryngeal muscular tension in patients with voice disorders. J Voice 2002;16: 333-43.

5. Kooijman PG, de Jong FI, Oudes MJ, Huinck W, van Acht H, Graamans K. Muscular tension and body posture in relation to voice handicap and voice quality in teachers with persistent voice complaints. Folia Phoniatr Logop 2005;57: 134-47.

6. Aronson AE. Clinical voice disorders. 3rd ed. New York: Thieme, 1990.

7. Rubin JS, Lieberman J, Harris TM. Laryngeal manipulation. Otolaryngol Clin North Am 2000; 33: 1017-34.

8. Roy N, Leeper HA. Effects of the manual laryngeal musculoskeletal tension reduction technique as a treatment for functional voice disorders: perceptual and acoustic measures. J Voice 1993; 7: 242-9.

9. Roy N, Ford C, Bless D. Muscle tension dysphonia and spasmodic dysphonia: the role of manual laryngeal tension reduction in diagnosis and management. Ann Otol Rhinol Laryngol 1996; 105: 851-6.

10. Ternström S, Andersson M, Bergman U. An effect of body massage on voice loudness and phonation frequency in reading. Logoped Phoniatr Vocol 2000; 25: 146-50.

11. Roy N. Assessment and treatment of musculoskeletal tension in hyperfunctional voice disorders. Int J Speech Lang Pathol 2008; 10: 195-209.

12. Roy N, Ferguson NA. Formant frequency changes following manual circumlaryngeal therapy for functional dysphonia: evidence of laryngeal lowering? J Med Speech Lang Pathol 2001; 9: 169-75.

13. Iwarsson J, Sundberg J. Effects of lung volume on vertical larynx position during phonation. J Voice 1998; 12: 159-65. 
14. Sundberg J, AskenfetA. Larynx height and voice source: a relationship? In: DM Bless DM, Abbs JH, eds. Vocal fold physiology: contemporary research and clinical issues. San Diego: College-Hill Press 1983: 307-16.

15. Shipp T. Vertical laryngeal position: research findings and applications for singers. J Voice1987; 1: 217-9.

16.Sonninen A. The external frame function in the control of pitch in the human voice. Ann N Y Acad Sci 1968;155: 68-90.

17. Mathieson L, Hirani SP, Epstein R, Baken RJ, Wood G, Rubin JS. Laryngeal manual therapy: a preliminary study to examine its treatment effects in the management of muscle tension dysphonia. J Voice 2009; 23: 353-66.

18. Roy N, Nissen SL, Dromey C, Sapir S. Articulatory changes in muscle tension dysphonia: evidence of vowel space expansion following manual circumlaryngeal therapy. JCommun Disord 2009; 42: 124-35.

19. Reimann AP, Siqueira LT, Rondon AV, Brasolotto AG, Silverio KC. Immediate effect of laryngeal manual therapy in dysphonic individuals. Codas 2016; 28: 59-65.

20. Cohen SM, Kim J, Roy N, Asche C, Courey M. Prevalence and causes of dysphonia in a large treatment-seeking population. Laryngoscope 2012; 122: 343-8.

21. Conde MCM, Siqueira LTD, Vendramini JE, Brasolotto AG, Guirro RRJ, Silverio. Transcutaneous electrical nerve stimulation (TENS) and laryngeal manual therapy (LMT): immediate effects in women with dysphonia. J Voice 2018; 32: 385. e17-385.e25.

22. Silverio KCA, Siqueira LTD, Lauris JRP, et al. Muscleskeletal pain in dysphonic women. Codas 2014; 26: 37481 .

23. Van Lierde KM, De Ley S, Clement G, Bodt DE, Van Cauwenberge P. Outcome of laryngeal manual therapy in four dutch adults with persistent moderate-to-severe vocal hyperfunction: a pilot study. J Voice 2004; 18: 467-74.

24. Rezaee Rad A, Moradi N, Shater Zadeh Yazdi MJ, et al. Efficacy of manual circumlaryngeal therapy in patients with muscle tension dysphonia. Shiraz E-Med J 2018; 19: e64478.

25. Silverio KCA, Brasolotto AG, Siqueira LTD, et al. Effect of application of transcutaneous electrical nerve stimulation and laryngeal manual therapy in dysphonic women: clinical trial. J Voice 2015; 29: 200-8.
26. Han JS, Chen XH, Sun SL, et al. Effect of low- and high-frequency TENS on met-enkephalin-Arg-Phe and dynorphin A immunoreactivity in human lumbar CSF. Pain 1991; 47: 295-8.

27. Hughes GS, Lichstein PR, Whitlock D, et al. Response of plasma betaendorphins to transcutaneous electrical nerve stimulation in healthy subjects. Phys Ther 1984; 64: 1062-6.

28. Alves Silverio KC, Brasolotto AG, Thaís Donalonso Siqueira L, Carneiro CG, Fukushiro AP, Roberto de Jesus Guirro R. Effect of application of transcutaneous electrical nerve stimulation and laryngeal manual therapy in dysphonic women: clinical trial. J Voice 2015; 29: 200-8.

29. Tomlinson CA, Archer KR. Manual therapy and exercise to improve outcomes in patients with muscle tension dysphonia: a case series. Phys Ther 2015; 95: 117-28. 